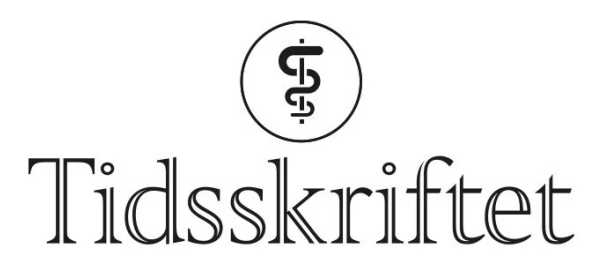

DEN NORSKE LEGEFORENING

\title{
Operasjon med robot
}

\author{
ANMELDELSER
}

ERIK FOSSE

Intervensjonssenteret

Oslo universitetssykehus

Gharagozloo, F

Najam, F

Robotic surgery

418 s, tab, ill. New York, NY: The McGraw-Hill, 2009. Pris USD 175

ISBN 978-0-07-145912-9

Dette er en lærebok for personell fra ulike kirurgiske disipliner som skal skaffe seg eller har anskaffet robot for spesifikke kirurgiske prosedyrer.

I første del presenteres de to kliniske robotene som ble lansert i slutten av 1990-årene, Zeus og da Vinci. Den sistnevnte er i dag den eneste som selges til klinisk bruk. Denne roboten beskrives i detalj, og det gis opplysninger om dekking av pasient og instrumenthåndtering og krav til operasjonsstuer.

I del 2- 5 beskrives erfaringer med roboter i hjertekirurgi, ikke-kardial thoraxkirurgi, generell kirurgi og urologi. Disse kapitlene inneholder mange detaljer om operasjonsteknikker, anestesi, leiring av pasient og plassering av porter og er derfor nyttig for alle som arbeider på operasjonsstuer der roboten benyttes.

I del 6 beskrives fremtidens operasjonsstuer og robotenes fremtidige rolle. Her diskuteres også betydningen av virtuelle simulatorer i opplæringen i robotkirurgi.

Det er forskjellige forfattere av hver del. Derfor er systematikken litt varierende, men uansett er dette en nyttig og lettlest bok. Den hører hjemme i de fleste avdelinger der man driver med robotkirurgi. Forfatterne konkluderer med at vi i det 21. århundre vil benytte mikro- og nanoroboter og at våre tradisjonelle kirurgiske metoder vil endres radikalt. Det er ikke vanskelig å være enig med dem i det.

Publisert: 11. mars 2010. Tidsskr Nor Legeforen. DOI: 10.4045/tidsskr.10.0o01

(C) Tidsskrift for Den norske legeforening 2023. Lastet ned fra tidsskriftet.no 26. april 2023. 